\title{
Study on Online Dispute Settlement Model of International Trade Disputes Against the Background of "the Belt and Road"
}

\author{
Li Ma \\ Law School \\ Sichuan Agriculture University \\ Ya'an, China
}

\author{
$\mathrm{Xin} \mathrm{Ni}$ \\ Law School \\ Sichuan Agriculture University \\ Ya'an, China
}

\begin{abstract}
Since 2013, when general secretary Xi Jinping put forward "the Belt and Road" cooperation initiative, 142 countries have participated till now. The promotion of "the Belt and Road" initiative has not only accelerated the crossborder trade cooperation among countries along the routes, but also brought about a series of trade frictions. Therefore, an efficient and convenient dispute settlement mechanism is particularly important. At the same time, in recent years, the "Internet plus" model has shown a hot trend, and the online dispute settlement mechanism combined with it has been discussed and studied by many scholars. This paper will start with the existing dispute settlement mechanism of countries along "the Belt and Road" and discuss the development prospect of online dispute settlement mode under the background of "the Belt and Road" by combining with the characteristics of the Internet.
\end{abstract}

Keywords-"the Belt and Road"; online dispute resolution; dispute resolution mechanism

\section{INTRODUCTION}

With the further development of "the Belt and Road" initiative, China's foreign trade has gradually accelerated and trade disputes have become more frequent. Under such a background, the online dispute settlement mode with the help of Internet advantages has obvious advantages in the settlement of international trade disputes. Based on the current situation of domestic law, some scholars in China have studied and practiced online arbitration, online mediation and other systems, trying to establish a new online dispute settlement model that is in line with the characteristics of the times and has Chinese characteristics. The other part of scholars focus on the international, combined with the emerging cross-border e-commerce transactions, to study the dispute resolution mechanism in cross-border e-commerce. But up to now, few scholars have explored the development ideas and direction of Online Dispute Settlement Mode in international trade disputes. The purpose of this paper is to make a preliminary exploration and conception of the online dispute settlement model of international trade disputes against the background of " the Belt and Road" through a large number of documents, analyzing relevant data, analyzing the existing online dispute settlement models and analyzing the existing dispute settlement mechanism of " the Belt and Road".

\section{Overview OF OnLine Dispute SeTtLement MOdEL}

\section{A. Concept and Development of Online Dispute Settlement Model}

With the advent of the era of big data, "Internet plus" technology is gradually popular. All kinds of platforms are connected with the Internet, and the judicial system is not left behind. Online dispute resolution (ODR) is a new type of dispute resolution that has developed rapidly in recent years. It mainly includes online consultation, online mediation, online arbitration and online litigation. Online consultation refers to the two parties through the Internet technology online communication to resolve the dispute. Online mediation is the use of network technology by both parties to reach an agreement on mediation with the participation of a third party. Online arbitration is mostly to build a virtual arbitration platform on the network, after the parties apply by the relevant organizations with the help of this platform for a series of arbitration procedures. For example, there is an arbitration online claim filing platform in the United States that deals with investment security. Parties can apply for online arbitration through this platform to safeguard their rights and interests. Online litigation is more complex in online dispute resolution, because the litigation procedure and entity content is more complicated than the mediation, arbitration, etc. But online litigation with the advantages of the Internet can not only facilitate the parties, but also can reduce the burden of the trial.

In recent years, all countries in the world are vigorously developing domestic online dispute settlement model. After more than a decade of development, the United States, the European Union and other regions have established a highlevel online dispute settlement platform represented by e-bay of the United States. At the same time, Japan, South Korea and other countries have also focused on the development of online dispute settlement models in recent years, and the use of the Internet as a dispute settlement platform has gradually 
come into people's lives. Such as Japan's "consumer life center" is already accepted by Internet trade disputes.

China has been trying to solve online disputes since 2004, and the first "China online dispute resolution center" was established under the guidance of China e-commerce law network. After many attempts and explorations, China has gradually implemented online arbitration, online trial and other systems in many parts of the country. E-commerce online courts were set up on a trial basis in Zhejiang province in 2015. China's first Internet court was set up in Hangzhou in 2017. Compared with "e-commerce court", "Internet court" can handle a wider range of cases, better system and higher judicial efficiency. This important innovation means that the ODR is formally incorporated into our legal system.

\section{B. Advantages and Disadvantages of Online Dispute Settlement Model}

The online dispute settlement mechanism has obvious advantages over the ordinary dispute settlement mechanism. The first online dispute settlement mechanism is not limited by geography and can resolve disputes across jurisdictions. With the rapid development of all kinds of trade, there are many trans-provincial and even transnational trade disputes in China. According to China's relevant laws, the jurisdiction of trans-provincial and municipal cases can still be determined through negotiation, while the jurisdiction of transnational cases has often become a big problem. The online dispute settlement mechanism can be completed online by means of information network, which can solve the jurisdiction problem naturally. At the same time, online arbitration and litigation also solved the question of the venue. Secondly, the online dispute settlement mechanism is cheaper than the traditional dispute settlement mechanism. Since most of the process is completed online, both parties can save money on transportation, room and board, and the dispute settlement agency can also reduce the processing cost. Finally, compared with traditional dispute settlement mechanism, online dispute settlement mechanism is more efficient and simple. Traditional arbitration and trial are limited by procedural process, which is often timeconsuming and inefficient to deal with disputes. However, online dispute settlement mode can not only change the previously tedious process, but also make the trial mode become flexible and greatly improve the efficiency of dispute settlement.

Of course, online dispute resolution as a new thing has its disadvantages. On the one hand, China's online dispute resolution laws and regulations are not complete and the process system is not perfect. Although China's online dispute resolution model started early, its development is slow. After more than 10 years of exploration, China began to pay more attention to online dispute resolution. But up to now, there is still no special laws and regulations to regulate the mode and process of online dispute resolution. On the other hand, the rapid development of network technology makes people's life gradually become "transparent". In the process of online dispute resolution, the privacy of the parties concerned has become a big problem because the materials need to be uploaded online. At present, most Chinese scholars are devoted to the study of online mediation, online arbitration and online litigation in China, trying to solve the problems existing in online dispute resolution, but few of them are abroad. In the author's opinion, China is a big country in foreign trade. Combined with the characteristics of "the Belt and Road" era, applying online dispute settlement mode to foreign trade disputes can make it play a significant role.

\section{Status Quo of Dispute Settlement Model AGAINST THE BACKGROUND OF "THE BELT AND ROAD"}

The construction of "the Belt and Road" not only accelerates the international trade of goods, but also promotes the economic and cultural exchanges among countries along the routes. But at the same time, a series of trade frictions will be accompanied by disputes between countries along the routes over investment, intellectual property rights and other aspects, as well as disputes among nationals of various countries over cross-border trade.

\section{A. Inter-state Dispute Settlement Mechanism and Its Disadvantages}

1) The dispute settlement mode and its disadvantages under the multilateral trade agreement - taking WTO as an example

The world trade organization (hereinafter referred to as "WTO") is the product of multilateral trade agreements. As an extremely important trade organization nowadays, it has solved trade disputes among many countries with a relatively complete dispute settlement model. The dispute settlement mode of WTO takes DSB, an authoritative dispute settlement institution, as the core, and DSU makes requirements on the specific procedures of dispute settlement, whose procedures mainly include consultation, mediation and mediation. Although the WTO dispute settlement mode is relatively complete at present, it still has some disadvantages combined with the characteristics of "the Belt and Road".

First of all, according to the data of WTO and China's official website of "the Belt and Road" by October 28, 2019, all the 14 disputes submitted to the WTO in 2019 had the participation of countries along "the Belt and Road", and 12 cases were appealed by countries along "the Belt and Road". It can be seen that countries along "the Belt and Road" are mostly at a disadvantage in the WTO dispute settlement mode, which is not conducive to the development of transnational trade. At the same time, the initiators of WTO are mainly developed countries, and the agreements under WTO are more to safeguard the interests of developed countries. For example, in the Uruguay round negotiations, the largest one to date, three new issues, involving trade in services, intellectual property and trade-related investment, added obligations to disadvantaged developing countries and more conducive to the trade activities of multinational companies in developed countries. The tilt protection not only makes the developing countries trade disputes cannot get fair treatment, more limits the trade development in developing countries. 
mechanisms: consultation, mediation or mediation and arbitration. CAFTA dispute settlement mechanism is established on the basis of WTO dispute settlement mechanism with reference to NAFTA dispute settlement mechanism. It has adjusted and improved the WTO dispute settlement mode according to the national conditions of participating countries, but this mode also has some disadvantages.

Firstly, as the signatories of a series of agreements on China- ASEAN Free Trade Area are all countries, the subject of the agreement on China- ASEAN dispute settlement mechanism is only a participating country like WTO, that is, only government is qualified to be a subject of CAFTA dispute settlement mechanism. Admittedly, this effectively prevented some private lawsuits from rising to the political level and maintained the political stability between countries. However, it is undeniable that with the development of international trade, more and more individuals have become the subject of transnational trade disputes, and their right to seek relief should be fully respected and guaranteed. In terms of quantity, the disputes between nationals of different countries along the routes are far more than those between countries. However, as far as the current situation is concerned, there is no dispute settlement mechanism applicable to private subjects.

Secondly, though there is agreement on the dispute settlement mechanism, but the author in the major related websites and found neither China - ASEAN free trade area or other countries along the Belt and Road route, are rarely reported, it is most because countries are more willing to take domestic relief measures to solve the majority of trade disputes, rather than resort to the dispute settlement mechanism. In my opinion, this can still be attributed to the high cost and low efficiency of the dispute settlement mechanism.

The third is the lack of relief. Different from the WTO dispute settlement mechanism, which has an appellate body, the decision made by the arbitration tribunal in the CAFTA dispute settlement mode is the final ruling. Although it upholds the authority of the arbitration tribunal, it greatly damages the rights of both parties to appeal, and it is difficult to guarantee the implementation of the award. Therefore, although a lot of space is spent in the agreement to stipulate arbitration as a dispute settlement method, few countries have adopted it in reality.

\section{B. Dispute Settlement Models of Different Countries and Their Drawbacks}

Up to now, there is no special dispute settlement mechanism to resolve the trade disputes between different countries along "the Belt and Road". The reason lies in the fact that the amount of subject matter between private subjects is often small and has little influence. If a special institution is set up, the cost of dispute settlement is likely to be higher. Therefore, people from different countries often resort to litigation and arbitration to settle cross-border trade disputes. But there are still practical drawbacks to both approaches. 
integrating them. After entering the panel procedure, written submissions and review meetings are required. After the panel's report is made, a party may apply to the appellate body for further review, and the appellate body only needs to convene a review meeting, which can be said to be largely written review. So these two procedures can also be completed online. There are three possible situations in the execution procedure. One is that the losing party implements the expert group report. The second is the losing party for certain compensation; the third is that the losing party does not do anything, and then the winning party can apply for retaliatory measures. These three scenarios are often not implemented in one step in reality, and both parties can fulfill progress by following online. In the FTA dispute settlement mechanism, most of them are revised based on the provisions of WTO, and almost all of these agreements resolve disputes through negotiation, mediation and arbitration. Based on this, the dispute settlement mechanism in FTA can be well integrated with online negotiation, online mediation and online arbitration.

Secondly, the integration of online dispute resolution model and traditional model has significant effects. Online consultation and mediation can effectively save both parties transportation costs, accommodation costs, materials costs, etc. It can be seen that the integration of the two can reduce the cost of dispute settlement. At the same time, it can reduce the possible time cost of both parties. For example, since the expert group in the WTO dispute settlement mechanism is non-permanent, the temporary establishment of the expert group to deal with the dispute after the plaintiff's request requires a certain amount of time from the application to the formation of the expert group, and these potential time costs can be reduced through the online mode. While reducing costs for both parties, the online dispute settlement mode also saves the cost of the WTO dispute settlement mechanism, enabling the appellate body to rehear the panel's report more carefully, so as to ensure the impartiality of the ruling as much as possible.

Finally, it is the idea of the integration of online dispute settlement mode and traditional mode. FTA dispute settlement mechanism is evolved from WTO dispute settlement mechanism. Therefore, this paper takes WTO dispute settlement mechanism as an example to discuss the idea of integrating traditional dispute settlement mechanism and ODR model. The WTO dispute settlement mechanism starts with the plaintiff's request for bilateral consultation with the defendant. Under the new mode, the request can be submitted through online network transmission, and electronic text can replace paper materials, which greatly improves the litigation efficiency. During the negotiation phase, the two parties can conduct a meeting via email or video, which requires less time and place and is more convenient. During the litigation phase, either the panel meeting or the appellate body meeting can be completed online, so that both parties do not need to gather in one place for litigation, which can save a lot of unnecessary costs. Panel reviews can be conducted at any time and place, providing greater confidentiality and saving on trial costs. The final decision report can also be published online, so that 
both parties can receive the result in the first time, litigation efficiency is significantly improved. In addition, all kinds of evidence materials in the whole process can be stored electronically, which not only reduces the use of paper, but also facilitates preservation. Of course, the "online" process does not exclude the "offline". Due to the particularity of some cases, the parties must negotiate face to face, which is inevitable. However, the whole dispute settlement process can still be based on the principle of "online settlement".

In conclusion, neither the WTO dispute settlement mechanism nor the FTA dispute settlement mechanism in the traditional mode can be well applied to the cross-border trade dispute settlement between countries along "the Belt and Road". Applying the online dispute settlement model to the traditional dispute settlement mechanism can promote the development of both simultaneously and make it more suitable for the basic requirements of "the Belt and Road".

\section{CONSTRUCTION OF THE ONLINE DisPUTE} SETTLEMENT MODEL OF DIFFERENT COUNTRIES ALONG THE ROUTES AGAINST THE BACKGROUND OF "THE BELT AND ROAD"

At present, the dispute settlement mechanism of countries along "the Belt and Road" almost all resolve the disputes between national governments. But with the further development of "area" initiative, more and more private subject to participate in the international trade, cross-border electricity, for example, 2019 The Belt and Road crossborder e-commerce consumption report show that China's cross-border electricity transaction has been from Eurasia expanded to Europe, Asia, Africa, the multinational, the types of the trading goods and trading frequency has great growth. In this process, a series of trade disputes have naturally arisen, and the litigation or arbitration methods often adopted in these disputes also have their shortcomings, making the settlement of disputes still have some practical problems. Therefore, it is necessary to build an online dispute settlement model suitable for the citizens of different countries along "the Belt and Road".

\section{A. Establishing a Legal Basis for Online Dispute Resolution}

Perfect rules and regulations are the basis of the operation of online dispute settlement mechanism. Both national policies and domestic legislation in countries along the Belt and Road should support the development of online dispute settlement models. Taking China as an example, the e-commerce law promulgated by China in 2018 stipulates that "operators of e-commerce platforms can establish online dispute resolution mechanism", which clarifies China's high recognition of online dispute settlement mode in crossborder e-commerce. However, in other aspects of transnational trade, the legislation of online dispute settlement by private subjects in China is still in a blank state. Therefore, China should define the online dispute settlement model in transnational trade by domestic legislation and make its effectiveness clear. At the same time, as the initiator of the The Belt and Road initiative, China should take the lead in further clarifying and refining relevant policies and legal provisions on online dispute settlement in different countries along the Belt and Road, so as to build a legal basis. "Area" initiative core with voluntary, equality, open for development, our country in building an online dispute resolution mechanism of legal basis, should pay attention to all the countries along the recognition degree of the rules, create accord with the actual conditions of most countries along the "area" system, make the voluntary participation, efficient and convenient to solve trade disputes.

\section{B. Forming an Online Dispute Settlement and Settlement Platform}

The essence of "the Belt and Road" initiative is a partnership agreement, not a system of rules. So far, there has not been a unified regulatory system among "The Belt and Road" participating countries, but this does not negate the importance of a unified normative system for the development of "The Belt and Road". The countries along the route of "The Belt and Road" have a great span in politics, economy and culture, so it is necessary to build a transnational online dispute settlement platform. Different from WTO, "The Belt and Road" does not have an official organ, so it is difficult to establish a unified platform. As the leader of the current global Internet technology industry and the leader of "The Belt and Road" initiative, China, as the initiator of "The Belt and Road" can invite countries along the routes to sign online dispute settlement agreements, jointly establish this transnational online dispute settlement platform, and jointly negotiate clear rules. The platform can not only be used for ordinary trade disputes between private parties, but also for consultation, mediation and litigation between countries. Dividing public and private subjects into two categories and dealing with them on the same platform not only saves costs but also ensures the smooth settlement of disputes. In this way, trade disputes between nationals of different countries along the routes no longer need to rely on domestic law for remedy, effectively preventing the issue of jurisdiction, application of law and excessive intervention of domestic law.

\section{Improving Online Dispute Resolution Technology}

One of the key factors for the development of online dispute settlement mechanism is the developed network information technology. Therefore, as the leader of "the Belt and Road", China must strive to improve its Internet technology level so as to improve the construction of online dispute settlement technology in international trade. First, cooperation with developed countries should be strengthened and learn from their experience in online dispute resolution. For example, the online dispute resolution model in the United States has developed for more than 10 years, and it has gradually become mature. However, China's online dispute resolution is still in its infancy, which needs to be studied and developed on the basis of drawing advanced experience. Secondly, it is necessary to develop effective technology carriers to improve the construction of online dispute resolution technology. Internet information technology can be embodied through software carrier. After improving its own technical level, China can take the lead in developing online dispute resolution related software, which 
can realize file transmission and preservation. The two sides online consultation and other functions. Finally, the construction of online dispute resolution technology needs to focus on privacy and protect the privacy of the parties. In trade disputes, the privacy of both parties should be protected, especially for enterprises. Enterprises may not only involve trade secrets, but even their disputes may rise to the national level once they are disclosed, so they should pay great attention to improving privacy protection technology.

\section{CONCLUSION}

Based on the above analysis, combined with the current situation of "the Belt and Road" dispute settlement mechanism, online dispute settlement mode has great development potential. It can not only combine with the existing mechanism, but also create a dispute settlement platform with its unique features. On the premise of advanced technical support, complete system guarantee and powerful platform construction, the online dispute settlement mode will surely provide a convenient way to resolve trade disputes in "the Belt and Road".

\section{REFERENCES}

[1] Zhao Qi. Discussion on China's Online Dispute Resolution Mechanism [D]. Shandong University,2019.

[2] Luo Sheng, Nie Changzhen. Development and Prospect of Online Dispute Settlement Mechanism under the Background of "The Belt and Road" $[\mathrm{J}]$. Review of International Law of Wuhan University,2018,2(02):25-36.

[3] Sun Xirong. Study on Legal Issues of Online Dispute Resolution Mechanism (ODR) [D]. Heilongjiang University,2017.

[4] Ni Nan. Research on the Construction of "The Belt and Road" Online Arbitration Settlement Mechanism for Trade Disputes [J]. Journal of Beijing Union University (Humanities and Social Sciences Edition), 2017(04):109-115+130.

[5] Pan Xinrong. Study on the Mechanism of Dispute Settlement in China-ASEAN Free Trade Area [D]. Jinan University,2015.

[6] Xu Chenglun. Research on the Construction of WTO Online Dispute Settlement Mechanism [J]. Journal of Chongqing University of Posts and Telecommunications (Social Science Edition),2012,24(05):38-44.

[7] Chen Youjie. Study on Legal Issues of Online Dispute Settlement Mechanism [D]. East China University of Political Science and Law,2005.

[8] Xie Genhua. Analysis on the Defects of WTO Dispute Settlement Mechanism [D]. East China University of Political Science and Law, 2001 . 